\title{
Raymond Farrin - Structure and Quranic Interpretation: A Study of Symmetry and Coherence in Islam's Holy Text
}

(Ashland, Oregon: White Cloud Press, 2014). xvii+163 pp.

ISBN: 978-1-93-595298-5 (paperback).

\section{by Muhammad Yaseen Gada, Aligarh Muslim University, India}

The coherence (nazm) and symmetry of the Qur'an have remained one of the most debated and discussed topics in the field of Qur'anic Studies; whether or not the Qur'anic surah or/and the whole Qur'an exhibit an organic unity has produced a plethora of books.

The book under review seeks to refute "the longstanding criticism of 'disjointedness"' in the Qur'an, aiming to illustrate how a better understanding of the Qur'an's structure will in turn help in our textual interpretation of it (p. xvi). The book draws mainly, among others, on Amin Ahsan Islahi (d. 1997) and Michel Cuypers. According to the former, each Qur'anic chapter is characterised by a "degree of unity" or a central theme, "Amud," that runs through a whole Surah. The Qur'an is not therefore a random text, as some believe but one which exhibits a precise structural plan, with a majority of chapters occuring in pairs; one chapter forms a pair with its adjacent chapter; pairs form chapter groups, and finally the chapter groups form the Qur'an as an organic unity. Cuypers, on the other hand, believes that there is a "degree of symmetry" among a group of chapters arranged in a concentric order. Farrin explores three types of symmetry: parallelism-AB/A'B'; chiasm- $\mathrm{AB} / \mathrm{B}^{\prime} \mathrm{A}^{\prime}$; and concentrism- $\mathrm{AB} / \mathrm{C} / \mathrm{B}^{\prime} \mathrm{A}^{\prime}$, the latter of which is prevalent in the Qur'an. Combining the two features make the Qur'an a complete organic unity according to Raymond Farrin.

Farrin attempts to demonstrate that "the whole Qur'an, including all its arranged parts, possesses a magnificent design" (p. xv). Arranged thematically, the book is divided into six chapters, an introduction, and a conclusion. Interestingly, Farrin provides, at the end, detailed appendices (pp. 75-121) documenting the symmetry of all 114 chapters.

The first chapter, "Framing the Qur'an", structurally discusses The Opening - the first chapter of the Qur'an. Farrin first provides a translation and then explains the meaning of each verse in its context. He maintains that the first three verses emphasise "Worship" (Mercy centred), which is connected to verses 5-6 that highlight "Supplication" (Mercy centred) and verse 4, which centres on "Worship and Supplication". In this way, he demonstrates that "The Opening has a concentric structure, consisting of two corresponding, outlaying parts- $[\mathrm{v}, 1-3$, and $\mathrm{v}, 5-6]$ themselves consisting of smaller rings - that encloses a central part [v, 4] relating to them" (p. 7). 
Similarly, he tries to relate the first chapter with that of the last $\left(114^{\text {th }}\right)$ chapter of the Qur'an. He points out that these chapters are similar both structurallyboth consist of six verses - and thematically_ "Prayer of Worship and Supplication" in the first chapter, and "Prayer of Refuge" in the last chapterwhile both contextualise humankind and the jinn. In this way, Farrin implies that Chapters 2-112 are in fact a Qur'anic guidance in response to the first chapter's supplication, while Chapters 113-114 portray a final prayer dispelling evil. This is an interesting observation to link the Qur'anic chapters in a coherent way. In this way, a reader becomes engaged with the Qur'an.

The second chapter, "The Chapter as Unity", demonstrates that the Qur'anic chapters feature structurally and thematically as an organic unity and as a coherent discourse. Here Farrin discusses the second chapter of the Qur'an, The Cow, as an example. He divides this chapter (on the basis of concentrism$\mathrm{ABC} / \mathrm{D} / \mathrm{C}^{\prime} \mathrm{B}$ ' $\mathrm{A}$ ') into seven sections; each carrying a central theme, and each connected to the adjacent section. The concentric pattern found in the second chapter are A-Believers vs. Disbeliever; B-Moses delivers law to Children of Israel; C-Abraham was tested; $\mathrm{D}-\mathrm{Ka}$ 'ba and a test for believers; C'Muslims will be tested; B'-Prophet delivers law to Muslims; and A'-Believers encouraged (struggle vs. disbelievers). Here Farrin points to an interesting inference that the previous traditions (Moses and Abraham) manifest continuity in the contemporary situation of the Prophet Muhammad (p. 20).

After discussing the principle of the Qur'anic chapter as a unity, Farrin explains in his third chapter the second structural principle that features in the Qur'an-“chapters tend to occur in pairs" (p. 22). Farrin mentions that it was Amin Ahsan Islahi who first discovered that the majority of Qur'anic chapters bear significant thematic and structural connections and form pairs with adjacent chapters. In addition, Farrin writes, Cuypers has highlighted that the last thirty chapters indeed occur in pairs. He examines the Chapters 113 and 114 (alMu'awwidhatan) - both have thematic and structural resemblance. Thematically, both seek God's protection from harm, and structurally both are short: each consists of six verses. Elaborating on this resemblance, Farrin writes that in "Chapter 113 one attribute is specified for God at the opening and then the threats are three, while in Chapter 114 three attributes are specified for God and then the threat is one" (p. 24). In this way, they together illustrate a chiastic pattern, and constitute a pair.

He then turns to long chapter pairs. For instance, he says that Chapter 2 (The Cow) deals particularly with the disputations of Jews, whereas Chapter 3 (The Family of 'Imran) deals especially with contentions of Christians; thus, as a pair, they respond to the arguments of the People of the Book (p. ibid). He also points out more thematic and structural correspondence between both Chapters. 
In Chapter four, "Chapter Pairs II", Farrin applies the same structural and thematic principle to medium-length pairs, such as Chapters 12 and 13, Joseph and Thunder. He explains in detail how these chapters relate to each other, as he did in the previous section.

The fifth chapter, "Chapter Groups", discusses the third structural principle evident in the Qur'an: the arrangement of pairs and certain individual chapters in coherent groups. Based on concentrism and parallelism, as indicated within individual chapters, Farrin finds nineteen groups altogether. The number of chapters indicated in each group varies from three to ten, with an average of six consecutive chapters forming a group. For instance, structurally Chapters 10-15 begin with the initial letters ALR that can be related to other Chapters 40-46 joined by the initial letter HM. Thematically, Chapters 10-15 highlight events of earlier prophets, which according to Farrin occur in concentric arrangement: an opening pair (10-11), a middle pair (12-13), and a closing pair (14-15). Farrin points out that the sequence indicates that "the first pair is linked to the last in that seven particular prophets are mentioned in Chapter 11 (Noah, Hud, Salih, Abraham, Lot, Shu'ayb, and Moses) and the same seven are mentioned or referred to again in Chapters 14-15". However, the middle pair, Farrin asserts, stands out, highlighting a long story of a single prophet, Joseph, in Chapter 12, and an additional initial letter ( $M$ in ALMR) in Chapter 13. This is an interesting observation on the group, and explains coherence in each group. However, he admits that the relationships he highlights in the groups are in no way comprehensive; there may be some other links that serve to prove the chapters are a discrete group.

In his sixth chapter, "The Central Group", Farrin discusses Chapters 50-56. According to Farrin, this group bears a striking structural and thematic coherence. He examines the group in two pairs (50-52 and 52-53), and three individual chapters $(54,55$, and 56$)$.

In the "Conclusion", Farrin sums up his discussion by emphasising that each chapter, pair, group and text exhibits a striking nazm (composition), structurally as well as thematically. He writes, "This consistency in underlying structure strongly suggests...that the entire Qur'an, form and content, traces directly to the Prophet [Muhammad]" (p. 71). Further, he observes that the unfinished tasks of the earlier prophets were accomplished in the personality of the Prophet Muhammad.

There are some criticisms which can be levied against Farrin's approach: Farrin's interpretation, such as his scheme of surah pairing, as adopted from Amin Ahsan Islahi, does not fit into the pattern he propounds; Secondly, the criteria he uses to arrange surahs into nineteen groups fails to explicate why a particular surah belongs to one group but not to the other. In addition, a reader may get 
obsessed with the structural nature of the Qur'an while ignoring the universality of the message of each and every verse.

There are also some contentious statements about the reality of some of his Qur'anic interpretations. For instance, Farrin describes the episode of the cow mentioned in the second chapter (The Cow) as "symbolic" (p. 13). Similarly, while interpreting references to the Garden, Fire, Heaven, and Hell, Farrin has assumed these images/objects concern the unseen and terms them as "similes" (p. 61), giving an impression of something that belongs solely to the hereafter. In doing so, Farrin seems to be narrowly reducing the Qur'an to a literary text.

Again, while dealing with Jews and Christians (p. 12), Farrin is quick to conclude that the Qur'an supports "religious pluralism" or the "equality" of all religion. This is an over simplification and rather superficial interpretation of the Qur'anic text, which is not comprehensive enough to satisfy a Muslim reader.

Limitations aside, the author should be commended for his efforts in highlighting the Qur'an as a structurally and thematically coherent and integrated whole. Simple in presentation, easy to understand, the book is a welcome contribution to the field of Islamic studies in general and Qur'anic studies in particular. 